Jurnal Nisbah Vol.5 No. 1 Tahun $2019 \mid \mathbf{4 5}$

\title{
MODEL PEMANTAUAN PRINSIP KEHATIAN-HATIAN ATAS FUNGSI KEPATUHAN PADA PERBANKAN SYARIAH DI INDONESIA
}

\section{MODEL OF MONITORING PRINCIPLES OF CAUTION FOR COMPLIANCE FUNCTION IN SHARIA BANKING IN INDONESIA}

\begin{abstract}
Irma Yuliani1a
1aFakultas Ekonomi dan Bisnis Islam Universitas Sunan Kalijaga Yogyakarta, Jl. Laksda Adisucipto, Papringan, Caturtunggal, Kec. Depok, Kabupaten Sleman, Daerah Istimewa Yogyakarta 55281, E-mail: irmayuliani82@gmail.com
\end{abstract}

\begin{abstract}
ABSTRAK
Penerapan terhadap prinsip kehati-hatian merupakan salah satu aspek penting dalam meningkatkan pemenuhan terhadap prinsip-prinsip syariah. Penelitian ini bertujuan untuk menyelidiki penerapan pemantauan terhadap prinsip kehati-hatian pada perbankan syariah di Indonesia. Selanjutnya penelitian ini dianalisis menggunakan pendekatan kualitatif deskriptif dengan menyelidiki beberapa fakta yang diperoleh dari laporan tata kelola perbankan syariah. Penelitian ini mengambil 10 sampel perbankan syariah untuk dijadikan objek dan diselidiki implementasi pemantauan prinsip kehati-hatiannya. Dari hasil penyelidikan diperoleh hasil bahwasannya hanya terdapat beberapa perbankan yang mengimplementasikan pemantauan terhadap prinsip kehati-hatian. Diantara perbankan yang menerapkan pemantauan tersebut yaitu BNI Syariah, Panin Bank Syariah, MayBank Syariah Indonesia, Bank Mega Syariah, Bank Muamalat Indonesia, serta BSM syariah. Selain ke enam bank tersebut, hampir sebagian besar melaporkan aktiftias pemenuhan kepatuhan syariah secara simpel dan kurang memisahkan masing-masing unit kerja.
\end{abstract}

Kata kunci: Perbankan syariah, Kepatuhan syariah, pemantauan prinsip kehati-hatian.

\begin{abstract}
The application of the precautionary principle is one of the important aspects in increasing compliance with sharia principles. This study aims to investigate the application of monitoring the precautionary principle in Islamic banking in Indonesia. Furthermore, this study was analyzed using a descriptive qualitative approach by investigating several facts obtained from sharia banking governance reports. This study took 10 samples of Islamic banking to become objects and investigated the implementation of monitoring the principle of prudence. The investigation revealed that there were only a few banks which implemented monitoring of the precautionary principle. Among the banks implementing such monitoring are BNI Syariah, Panin Syariah Bank, MayBank Syariah Indonesia, Mega Syariah Bank, Muamalat Indonesia Bank, and Sharia BSM. In addition to the six banks, almost the majority reported the simple fulfillment of Shariah compliance activities and lack of separating each work unit.
\end{abstract}

Keywords: Islamic banking, Shariah compliance, monitoring prudential principles. 
Irma Yuliani. 2019. Model Pemantauan Prinsip Kehati-hatian Atas Fungsi Kepatuhan Pada Perbankan Syariah di Indonesia. Nisbah: Jurnal Perbankan Syariah 5 (1): 45-54.

\section{PENDAHULUAN}

Sebagai negara yang didominasi oleh populasi muslim, Indonesia merupakan salah satu ladang yang potensial bagi pengembangan industri keuangan syariah. Meningkatnya kepercayaan masyarakat terhadap pelayanan lembaga keuangan syariah harus diiringi dengan meningkatnya kinerja manajemen maupun kepatuhan syariah dari internal lembaga. DPS merupakan icon penting dibalik terwujudnya kepatuhan syariah. Di Indonesia, DPS berkedudukan sebagai elemen independen yang berperan dalam hal merencanakan, mengontrol, mengevaluasi serta melaporkan segala sesuatu yang berkaitan dengan kinerja syariah sebuah LKS (Ilhami, 2009; Nurhikmah \& Kusumaningtyas, 2018; Widyanto, 2010).

Prinsip syariah tidak hanya dipandang sebagai nilai moral yang membedakan antara lembaga syariah dengan lembaga konvensional, namun prinsip syariah adalah sebuah nilai yang akan dipertaruhkan jika suatu lembaga tidak mampu mempertahankan kepatuhan syariah di mata publik (Mardiyah \& Mardian, 2015), sehingga prinsip syariah akan menjadi sumber risiko yang rentan dan timbul dalam berbagai aspek kegiatan lembaga (Faozan, 2013; Khoirudin, 2013). Untuk itu, dalam rangka mewujudkan tujuan syariah maka dibutuhkan DPS yang professional dan dapat menjaga citra baik suatu lembaga (Prabowo \& Jamal, 2017; Prasetyoningrum, 2010; Riani \& Mardian, 2017). Tidak hanya itu, DPS yang professional akan mempengaruhi kinerja manajemen baik secara langsung maupun tidak langsung (Nurhikmah \& Kusumaningtyas, 2018; Yazid \& Suryanto, 2016).

Selama 26 tahun terakhir, dinamika sektor perbankan syariah di Indonesia menunjukkan perkembangan yang cukup pesat. Terhitung sejak tahun 1992 hingga 2018 sudah terdapat 13 BUS yang beroperasi dan berpartisipasi aktif dalam memberikan pelayanan keuangan syariah. Meskipun demikian, di sisi lain terdapat bagian vital yang masih jarang mendapatkan perhatian baik dari praktisi maupun akademisi di bidang keuangan syariah, yaitu minimnya pengkajian dan penelitian mengenai upaya-upaya dalam meningkatkan kredibilitas lembaga keuangan syariah, terutama mengenai kepatuhan. Sebagian besar literature hanya berbicara mengenai prospek kinerja lembaga, market share, risiko, serta upaya-upaya lain yang berkaitan dengan pengembangan lembaga, namun masih jarang sebuah kajian yang melakukan diagnosis terhadap kinerja kepatuhan dan upaya untuk meningkatkan kredibilitas terkait dengan kepatuhan syariah.

\section{MATERI DAN METODE}

\section{Perbankan Syariah di Indonesia}

Secara filosofi, perbankan syariah hadir sebagai wajah baru yang menampilkan sistem perbankan yang aktifitasnya bebas dari riba. Alasan filosofis ini didasarkan perintah dalam alQur'an yang menyebutkan pelarangan terhadap riba: 
"Allah menghalalkan jual beli dan mengharamkan riba...(Q.S. Al-Baqarah (2): 275).

Ayat al-Qur'an tersebut merupakan landasan filosofis yang tidak pernah ditinggalkan dalam membumikan sistem ekonomi islam (Machmud \& Rukmana, 2010). Selanjutnya UUD No. 21 Tahun 2008 tentang perbankan syariah mendefinisikan perbankan syariah sebagai segala sesuatu yang menyangkurt tentang Bank Syariah dan Unit Usaha Syariah, mencangkup kelembagaan, kegiatan usaha, serta cara dan proses dalam melaksanakan kegiatan usahanya. Maka dengan diberlakukannya UUD No. 21 tahun 2008 menegaskan bahwa secara eksplisit segala transaksi perbankan syariah wajib patuh dan berlandaskan pada hukum dan prinsip-prinsip syariah (Anshori, 2010).

Hadirnya perbankan syariah di Indonesia yang menciptakan dual system pada industri perbankan memberikan sarana kepada masyarakat untuk bersama-sama membumikan serta berpartisipasi dalam mendukung peran perbankan syariah terhadap pengelolaan ekonomi makro. Karakteristik perbankan syariah yang beroperasi berdasarkan prinsip syariah terlebih juga memberikan alternatif kepada masyarakat yang memiliki kecenderungan untuk berinvestasi maupun bertransaksi dengan mempertimbangkan prinsip keadilan, etika, nilai bekerjasama, nilai persaudaraan dalam berproduksi serta menghindari kegiatan spekulatif $(\mathrm{OJK}$, 2019).

Dalam meningkatkan dan pengembangkan industri perbankan syariah, di Indonesia arah pengembangan perbankan syariah terbagi menjadi dua, yaitu pencapaian jangka pendek dan jangka panjang. Dalam jangka pendek, perbankan syariah di Indonesia akan lebih diarahkan untuk memenuhi pasar domestik dengan terus meningkatkan kualitas layanan dan kinerja yang bertaraf internasional. Sedangkan dalam jangka panjang atau sepuluh tahun yang akan datang pencapaian perbankan syariah di Indonesia akan diarahkan pada pencapaian pangsa pasar yang signifikan melalui pendalaman peran perbankan syariah dalam aktivitas keuangan nasional, regional dan internasional dengan terus mengintegrasikan dengan sektor keuangan syariah yang lainnya.

Dalam kurun waktu dua puluh tujuh tahun terakhir ini, perkembangan perbankan di Indonesia terus mengalamai peningkatan, hal ini terbukti bahwa ratarata pertumbuhan aset perbankan syariah mencapai $65 \%$ pertahun, dengan 14 jumlah Bank Umum Syariah yang telah beroperasi. Inovasi produk dan aspek hukum juga terus mengalami peningkatan, hal ini tidak lain bertujuan agar perbankan syariah semakin meningkatkan nilai inklusifitas dan kredibilitasnya di kalangan masyarakat Indonesia dan juga dunia Internasional.

\section{Prinsip-prinsip syariah dalam sistem hukum perbankan syariah di Indonesia}

Hadirnya perbankan syariah di Indonesia merupakan aktualisasi dari kebutuhan masyarakat yang menghendaki sistem perbankan yang mampu menyediakan jasa keuangan yang berpegang teguh pada prinsip syariah. Namun demikian agar perbankan dapat menjalankan fungsi dan perannya dengan baik maka perlu adanya payung hukum yang berlaku secara formal. Secara umum payung hukum operasional perbankan syariah di Indonesia terdiri dari macam, yaitu landasan hukum konstitusi dan peraturan perundang-undangan (Burhanuddin, 2010). Landasan konstitusi didasarkan pada pasal 29 ayat 2 Undangundang Dasar Tahun 1945. Sedangkan 
peraturan perundang-undangan yang mengawalinya meliputi UU No. 23 Tahun 1999 tentang Bank Indonesia, UU No. 3 Tahun 2004 tentang Perubahan atas UU No. 23 Tahun 1999, Ketentuan UU No. 7 Tahun 1992 tentang Perbankan, UU No. 10 Tahun 1998 tentang Perubahan atas UU No. 7 Tahun 1992 tentang Perbankan, serta Undang-undang No. 21 Tahun 2008 tentang Perbankan Syariah. Seluruh payung hukum tersebut tidak lain bertujuan agar perabankan syariah dapat terus menjalankan operasinya secara optimal dan tidak bertentangan dengan prinsip hukum positif maupun prinsip syariah (Burhanuddin, 2010).

Prinsip syariah sendiri dalam UU No. 21 Tahun 2008 pasal 1 angka 12 didefinisikan sebagai prinsip hukum islam dalam kegiatan perbankan berdasarkan fatwa yang dikeluarkan oleh lembaga yang memiliki kewenangan dalam penetapan fatwa di bidang syariah. Merujuk pada UU tersebut maka dapat ditarik kesimpulan bahwa lembaga yang berwenang dalam penetapan fatwa adalah Desan Syariah Nasional-Majelis Ulama Indonesia (DSNMUI) (Anshori, 2010).

Selain perundang-undangan yang disebutkan di atas, prinsip hukum perbankan syariah juga didasarkan pada hukum islam, hukum perbankan syariah bagian dari hukum ekonomi islam, hukum ekonomi islam bagian dari hukum islam, dengan demikian prinsip hukum islam berlaku dalam hukum perbankan syariah. Adapun prinsip-prinsip hukum perbankan syariah tersebut yang dirangkum dari tulisan Shomad (2010) diantaranya (Shomad, 2010):

a. Prinsip Aqidah atau prinisp tauhidullah, prinnsip ini menekankan bahwa harta benda yang kita kuasai adalah amanah dari Allah, untuk itu manusia hanyalah wakil Allah di muka bumi. Selain itu, prinsip ini juga menjelaskan adanya hubungan secara langsung antara manusia dengan Allah

b. Prinsip tasyri'iyyah, , yaitu prinsip yang menekankan bahwa semua persoalan harus kembali kepada AlQur'an dan Sunnah sebagai pedomannya

c. Prinsip kaffah, artinya hukum yang digunakan dalam transaksi syariah harus berlandaskan pada hukum islam, bagi kita yang meyakini hukum syariah maka dianjurkan untuk melaksanakan ketentuan syariah dalam segala aspek gerak kehidupan kita.

d. Prinsip Akhlak, etika berbisnis menjadi acuan utama dalam bisnis modern yang mulai kembali merangkul ruh religiusitas. Dari prinsip ini muncul kewajiban dalam diri setiap individu untuk memegang teguh nilai kejujuran dan kebenaran.

e. Prinsip transaksi yang meragukan dilarang, akad dalam setiap transaksi harus tegas, jelas, dan pasti. Baik benda yang menjadi objek akad, maupun harga barang yang diakadkan itu.

f. Prinsip transaksi yang merugikan dilarang, setiap transaksi yang merugikan diri sendiri maupun pihak luas dilarang, sebagaimana sabda Rasulullah: "Tidak boleh membahayakan (merugikan) diri sendiri dan tidak boleh membahayakan (merugikan) pihak lain."

g. Prinsip mengutamakan kepentingan sosial, prinsip ini menekankan bahwa kepentingan bersama harus didahulukan tanpa merugikan kepentingan individu, hal ini sesuai dengan kaidah fiqhiyyah yang menyebutkan "Bila bertentangan antara kemaslahatan sosial dan 
kemaslahatan individu, maka diutamakan kepentingan sosial."

h. Prinsip maslahat, prinsip ini merupakan tujuan akhir yang ingin dicapai oleh tujuan syariah (maqashid as-syariah). Maslahat berarti sesuatu yang menghadirkan kebaikan dan keselamatan.

\section{Fungsi Kepatuhan Syariah}

Penerapan terhadap prinsip-prinsip syariah merupakan faktor penting yang memberdakan antara sistem perbankan konvensional dengan perbankan syariah. Mengacu pada Peraturan Bank Indonesia Nomor 13/2/PBI/2011 tentang pelaksanaan kepatuhan, maka kepatuhan didefinisikan sebagai seperangkan nilai, perilaku, tindakan yang medukung terciptanya kepatuhan terhadap ketentuan Bank Indonesia dan peraturan perundang-undangan yang berlaku, termasuk prinsip syariah bagi Bank Umum Syariah dan juga Unit Usaha Syariah (Bank Indonesia, 2011).

Arifin (2009) mendifinisikan kepatuhan syariah dalam Bank Syariah sebagai penerapan prinsip-prinsip islam, syariah dan tradisinya dalam transaksi keuangan dan perbankan serta bisnis lain yang terkait (Arifin, 2009). Di sisi lain, Anshori (2010) mengungkapkan kepatuhan syariah sebagai salah satu indikator pengungkapan islami untuk menjamin kepatuhan bank islam terhadap prinsip syariah (Anshori, 2010). Sedangkan menurut Sutedi (2009) kepatuhan syariah merupakan kepatuhan kepada Dewan Syariah Nasional (DSN) yang teraktualisasi melalui kepatuhan terhadap fatwa DSN, sebab fatwa DSN merupakan perwujudan prinsip dan aturan syariah yang harus ditaati dalam perbankan syariah. Bank Indonesia mengatur kepatuhan suatu perbankan syariah diantaranya meliputi pemenuhan ukuran prinsip syariah baik dalam produk, transaksi, dan operasional bank syariah (Sutedi, 2009).

Dalam melaksanakan mekanisme kepatuhan syariah, terdapat dua konsep yang mendasari pelaksanaan pengawasan syariah guna memenuhi akuntabilitas secara horisontal maupun transendental. Yang pertama adalah konsep sharia review yang harus dilakukan oleh Dewan Pengawas Syariah (DPS) untuk melakukan pengawasan terhadap kepatuhan syariah. Dan yang kedua adalah konsep internal sharia review sebagai salah satu fungsi audit internal untuk menilai kesesuaian operasi dan transaksi dengan prinsipprinsip syariah yang telah ditentukan (Ardhaningsih, 2012).

\section{Prinsip Kehati-hatian}

Dalam melaksanakan segala transaksi keuangan, operasional perbankan syariah harus mengacu pada prinsip kehati-hatian. Prinsip kehatihatian didefinisikan sebagai asas atau prinsip yang menyatakan bahwa dalam menjalankan segala aktifitas sebuah lembaga harus mendahulukan sikap kehati-hatian dalam rangka menjaga amanah masyarakat melalui dana yang dikelola oleh lembaga tersebut (Usman, 2001). Hal ini juga searah dengan tujuan perbankan sebagaimana yang tercantum dalam UU No. 10 Tahun 1998 pasal 2 yang berbunyi "Perbankan Indonesia dalam melakukan usahanya berasaskan demokrasi ekonomi dengan menggunakan prinsip kehati-hatian".

Prinsip kehati-hatian harus diterapkan oleh perbankan bukan sekedar sebagai kewajiban perbankan dalam melindungi aset nasabah atau agar tidak merugikan nasabah, terlebih diterapkannya prinsip kehati-hatian bertujuan agar perbankan atau lembaga keuangan dapat menjalankan usahanya dengan baik dan mematuhi segala ketentuan serta norma-norma hukum 
yang berlaku, ketika lembaga keuangan yang bersangkutan selalu dalam keadaan sehat maka masyarakat juga akan semakin mempercayainya, dengan begitu akan tercipta operasional perbankan yang efektif dan efisien.

\section{Metode Penelitian}

Penelitian ini mengambil sampel beberapa perbankan syariah di Indonesia untuk diselidiki model pemantaun prinsip kehati-hatian pada masing-masing perbankan. Adapun Perbankan syariah yang diambil sebagai sampel penelitian diantaranya Bank Negara Indonesia (BNI) Syariah, Bank Syariah Mandiri, Bank Muamalat, Bank Rakyat Indonesia (BRI) Syariah, Bank Mega Syariah, BJB Syariah, MayBank Syariah Indonesia, Panin Bank Syariah, Bank Central Asia (BCA) Syariah, Serta Bank Victoria Syariah. Melalui sepuluh Bank Umum Syariah tersebut, data dikumpulkan dari laporan Tata Kelola perusahaan. Selain laporan tata kelola perusahaan, data juga dikumpulkan dari berbagai publikasi Otoritas Jasa Keuangan (OJK), Website, serta laporanlaporan lain yang relevan dengan isu permasalahan. Penelitian ini menggunakan pendekatan kualitatif deskriptif dalam menganalisis data. Hasil yang diharapkan dari penelitian ini berupa analisis model pemantauan prinsip kehati-hatian oleh perbankan syariah di Indonesia dalam rangka meningkatkan kinerja kepatuhan lembaga.

\section{HASIL DAN PEMBAHASAN}

\section{Model Implementasi Pemantauan Prinsip Kehati-hatian pada Perbankan Syariah di Indonesia}

Pemantauan prinsip kehati-hatian merupakan salah satu bentuk pelaksanaan atas fungsi kepatuhan. Prinsip kehatihatian akan diterapkan oleh perbankan untuk menghindari segala kemungkinan terjadinya ketidaksengajaan pada aktifitas atau transaksi perbankan. Oleh karena itu prinsip kehati-hatian perlu dilaksanakan guna mewujudkan fungsi kepatuhan secara optimal. Dalam melaksanaan fungsi kepatuhan, masing-masing Perbankan syariah di Indonesia memiliki karakteristik dan model pemantauan yang berbeda-beda, tentu penerapan hal tersebut disesuaikan dengan kerangka dan ukuran kinerja yang hendak dicapai oleh masing-masing lembaga. Dalam artikel ini, akan dipaparkan berbagai model pemantauan prinsip kehati-hatian dan realisasinya pada masing-masing lembaga perbankan.

Dalam menjalankan fungsi kepatuhan, perbankan syariah di Indonesia mengacu pada Peraturan Otoritas Jasa Keuangan No. 46/POJK.03/2017 tentang pelaksanaan fungsi kepatuhan Bank Umum. Adapun tugas dan tanggung jawab yang dilaksanakan oleh Perbankan Syariah di Indonesia berdasarkan peraturan tersebut ialah sebagai berikut:

a. Membuat langkah-langkah dalam rangka mendukung terciptanya Budaya Kepatuhan pada seluruh kegiatan usaha Bank pada setiap jenjang organisasi,

b. Melakukan identifikasi, pengukuran, monitoring, dan pengendalian terhadap Risiko Kepatuhan dengan mengacu pada peraturan Otoritas Jasa Keuangan mengenai Penerapan Manajemen Risiko bagi Bank Umum Syariah,

c. Menilai dan mengevaluasi efektivitas, kecukupan, dan kesesuaian kebijakan, ketentuan, sistem maupun prosedur yang dimiliki oleh Bank dengan Peraturan Perundang-undangan yang berlaku,

d. Melakukan review dan/atau merekomendasikan pengkinian dan 
penyempurnaan kebijakan, ketentuan, sistem maupun prosedur yang dimiliki oleh Bank agar sesuai dengan ketentuan regulator (Otoritas Jasa Keuangan) dan Peraturan Perundangundangan yang berlaku, termasuk Prinsip Syariah,

e. Melakukan upaya-upaya untuk memastikan bahwa kebijakan, ketentuan, sistem dan prosedur, serta kegiatan usaha Bank telah sesuai dengan ketentuan regulator (Otoritas Jasa Keuangan) dan Peraturan Perundang-undangan yang berlaku,

f. Melakukan tindakan pencegahan agar kebijakan dan/atau keputusan yang diambil Direksi Bank tidak menyimpang dari ketentuan regulator (Otoritas Jasa Keuangan) dan Peraturan Perundang-undangan yang berlaku,

g. Melakukan tugas pelaporan kepatuhan kepada Direktur Utama melalui Direktur yang membawahkan fungsi kepatuhan dengan tembusan kepada Dewan Komisaris; dan

h. Melakukan tugas-tugas lainnya yang terkait dengan Fungsi Kepatuhan.

Pada Bank Negara Indonesia (BNI) Syariah, pelaksanaan atas fungsi kepatuhan terbilang sudah cukup bagus, hal ini dapat dilihat dari laporan tata kelola perusahaaan yang dipublikasi oleh lembaga di setiap tahunnya. Selain melaksanakan fugsi kepatuhan saebagiamana yang dilakukan oleh Perbankan Syariah pada umumnya, BNI Syariah juga mengatur kerangka kinerja secara rapi sehingga dibentuk unit-unit tertentu dalam mengoptimalkan fungsi kepatuhannya. Misalnya seperti unit pemantauan prinsip kehati-hatian. Melalui unit kerja tesebut, realisasi kegiatan yang dilakukan oleh BNI Syariah selama tahun 2017 diantaranya: a. Melakukan Checklist Uji Kepatuhan usulan pembiayaan sebanyak 53 (lima puluh tiga) kali.

b. Melakukan Checklist Uji Kepatuhan penempatan dana (financing line) sebanyak 27 (dua puluh tujuh).

c. Melakukan Checklist Uji Kepatuhan pengadaan barang \& jasa yang diputus kewenangannya oleh Direksi sebanyak 9 (sembilan) kali.

d. Melakukan Checklist Uji Kepatuhan pembukaan/pemindahan jaringan kantor sebanyak 28 (dua puluh delapan) kali.

e. Memberikan opini kepatuhan syariah sebanyak 36 (tiga puluh enam).

Unit kerja BNI Syariah yang menangani pemantauan prinsip kehatihatian tersebut telah beroperasi sejak tahun 2014, hal ini terbukti selama empat (4) tahun terakhir hingga tahun 2017 pada laporan tata kelola perusahaan disampaikan laporan pemantauan tersebut. Pada tahun 2013 pelaksanaan fungsi kepatuhan masih dilakukan secara umum sebagaimana yang dilakukan oleh perbankan lain pada umumnya, pemantauan prinsip kehati-hatian belum termasuk ke dalam unit kerja yang independen, namun pelaksanaa atas prinsip kehati-hatian sudah mulai dilaksanakan secara teratur dan selalu dilaporkan, hal ini terbukti pada tahun 2012 dan juga tahun 2012 dalam memastikan kegiatan usaha BNI Syariah telah sesuai dengan ketentuan Bank Indonesia dan peraturan perundangperundangan yang berlaku telah dilakukan uji kepatuhan terhadap usulan pembiayaan, uji kepatuhan terhadap usulan pengadaan barang dan jasa yang menjadi kewenangan Direksi, dan juga uji kepatuhan terhadap usulan financingline.

Berbeda dengan BNI Syariah, Bank Syariah Mandiri (BSM) juga memastikan fungsi kepatuhannya melalui prinsip 
kehati-hatian. Namun realisasi kegiatan tersebut terwujud dalam unit kerja yang berbeda, BSM melaksanakan aktifitas prinsip kehati-hatian tersebut melalui pelaksanaan koordinasi dengan Dewan pengawas Syariah (DPS). Selama tahun 2017 antara CPG dengan Dewan Pengawas Syariah terlaksana kegiatan uji petik yang telah sebanyak 12 (dua belas) kali. Adapun cakupan pengawasan aspek syariah meliputi:

a. Pendampingan DPS pada Uji Petik, yaitu dengan melakukan pemeriksaan dokumen pembiayaan kepada unit kerja yang menjadi obyek Uji Petik DPS diantaranya pembiayaan dan pendanaan dengan basis akad (Murabahah, Mudharabah, Musyarakah, termasuk Musyarakah Mutanaqisah, Ijarah, termasuk Ijarah Muntahiya Bit Tamlik, Pembiayaan Take Over, baik dari Lembaga Keuangan Konvensional maupun Lembaga Keuangan Syariah, Pembiayaan dengan tujuan Refinancing, Pembiayaan kepada Koperasi, Formulir Pembukaan Rekening Tabungan, Giro, dan Deposito).

b. Metode pemeriksaan dilakukan secara on desk dan on site dengan pemeriksaan melalui dokumen serta wawancara kepada Unit Kerja (Area/Cabang) terkait.

c. Memastikan terpenuhinya aspek Syariah dalam forum komite pembiayaan level Direksi dengan menghadiri Rapat Teknis dan Rapat Komite Pembiayaan Level Direksi.

Dalam melaksanaan pemantauan prinsip kehati-hatian BSM belum membentuk unit kerja secar khusus sebagaimana yang dilakukan oleh BNI Syariah sebelumnya. Namun secara garis besar, aktifitas pemantauan ini telah dilakukan oleh BSM yang terwujud dalam model yang berbeda, akan tetapi tujuan dari kegiata tersebut sama, yaitu meningkatkan peran fungsi kepatuhan secara optimal.

Hal yang sama juga dilakukan oleh Bank Muamalat Indonesia. Dalam rangka mewujudkan fungsi kepatuhan ia juga melalukan beberapa strategi. Pada tahun 2017, kerangka kerja yang secara khusus menjelaskan tentang pemantauan prinsip kehati-hatian belum terpapar pada unit kerja yang terpisah, namun secara garis besar pelaksanaan sharia complaince telah direalisasikan sabagaimana yang dijelaskan dalam pelaksanaan fungsi kepatuhan bagian "Pengelolaan dan Mitigasi Risiko Kepatuhan”. Bank Muamalat juga melakukan Compliance Checklist yang bertujuan untuk memastikan kesiapan operasional pembukaan, pemindahan alamat dan perubahan status kantor sebelum pengajuan yang disampaikan kepada Otoritas Jasa Keuangan (OJK). Selain itu, sebagaimana perbankan syariah pada umumnya, salah satu bagian penting dalam pelaksanaan fungsi kepatuhan juga dilakukan penyampaian opini, review, reminder dan sharing info ketentuan/peraturan terkait Kebijakan dan/atau prosedur terkait pembiayaan, pemenuhan ketentuan syariah dalam pembiayaan dan fatwa.

Pada Bank Rakyat Indonesia (BRI) Syariah, pelaksanaan fungsi kepatuhan masih terbilang cukup umum, sehingga unit kerja khusus yang menangani pemantauan prinsip kehati-hatian belum ditemukan. Hal ini terbukti pada tahun 2017 dilaporan bahwa pelaksanaan fungsi kepatuhan sebagai berikut:

a. Menunjuk direktur kepatuhan serta memiliki unit kerja kepatuhan yang independen terhadap stuan kerja operasional sesuai dengan kebutuhan dan ukuran bank, 
b. Membuat kebijakan dan prosedur kepatuhan,

c. Menyediakan informasi mengenai ketentuan yang berlaku dan melakukan monitoring terhadap pelaksanaannya,

d. Melakukan monitoring terhadap ketersediaan pedoman kerja pada setian unit kerja serta melakukan updet terhadap pedoman kerja tersebut, dan lain sebagainya.

Fenomena yang berbeda ditemukan pada Bank Mega Syariah, dalam rangka melaksanakan fungsi kepatuhan, Bank Mega syariah memiliki model yang berbeda dengan perbankan yang lainnya, Misalnya dalam memberikan pemahaman atas aspek kepatuhan, bank mega memberikan training kepada para pegawai serta menyampaikan pesan melalui sarana email tentang pesan-pesan kepatuhan, seperti larangan riba atas terhadap transaksi yang dilaksanakan perbankan, memantau risiko, merahasiakan data nasabah, dll. Selain itu, untuk melaksanakan prinsip kehati-hatian Bank Mega juga memantau Batas Maksimum Penyediaan Dana (BMPD), Modal Inti Bank, Non Performing Financing (NPF), Giro Wajib Minimum (GWM), dan Kecukupan Pemenuhan Modal Minimum (KPMM), serta melaksanakan monitoring unit kerja yang lainnya. Namun dalam hal ini dapat disimpulkan bahwa unit kerja yang secara khusus menangani pemantauan prinsipprinsip kehati-hatian belum dibentuk oleh Bank Mega Syariah, atau dengan kata lain Bank Mega Syariah memiliki model yang berbeda dalam memastikan kehati-hatian pada pelaksanaan fungsi kepatuhan.

Pelaksanaa fungsi kepatuhans secara sederhana juga ditemukan pada BJB Syariah. Pada tahun 2017, pelaksanaan prinsip kehati-hatian mulai diterapkan, namun belum terwujud melalui unit kerja yang independen, sehingga kerangka kerja masih umum sebagaimana uni kepatuhan perbankan secara universal.

Sebagai salah satu Bank Swasta Asing yang mengoperasikan usahanya di Indonesia, dalam melaksanakan prinsip kehati-hatian MayBank lebih mengutamakan pada pengkajian ulang terkait pengajuan dan pelaporan produk dan aktivitas baru dalam rangka memperoleh persetujuan dari regulator dan memastikan agar produk dan aktivitas baru tersebut sesuai dengan peraturan regulator serta bekerjasama dengan unit kerja terkait dalam melakukan monitoring atas pengajuan produk dan aktivitas baru sampai dengan realisasinya. Selain itu juga melakukan kaji ulang dan/atau merekomendasikan pengkinian dan penyempurnaan kebijakan, ketentuan, sistem maupun prosedur Bank agar sesuai dengan ketentuan regulator dan juga prinsipprinsip Syariah, diantaranya yaitu:

a. Melakukan sosialisasi perubahan ketentuan regulator maupun ketentuan regulator yang baru kepada unit kerja terkait, termasuk membuat gap analysis atas kondisi Bank saat ini.

b. Melakukan pengkinian atas ketentuan-ketentuan internal Bank.

Dalam kata lain pelaksanaan pemantauan prinsip kehati-hatian belum dilaksanakan secara khusus oleh MayBank Syariah Indonesia. Selain itu, model yang berbeda juga dilakukan oleh Panin Bank Syariah. Selama tahun 2018, penerapan prinsip kehati-haitan pada Fungsi Kepatuhan dilaksanakan dalam bentuk:

a. Melakukan monitoring dalam pelaksanaan ketentuan prinsip kehatihatian seperti Kewajiban Penyediaan Modal Minimum/Capital Adequacy Ratio (CAR), Batas Maksimum Penyaluran Dana (BMPD), 
NonPerforming Financing (NPF), Penyisihan Penghapusan Aktiva (PPA) dan Giro Wajib Minimum (GWM).

b. Menyampaikan Opini Kepatuhan kepada unit kerja terkait dan kantorkantor cabang mengenai rancangan kebijakan dan ketentuan, pelaksanaan operasional, produk maupun program baru dan aktivitas lainnya yang berhubungan dengan aspek general compliance maupun aspek syariah terhadap 83 (delapan puluh tiga) opini.

c. Melakukan kajian kepatuhan terhadap usulan pembiayaan dengan limit usulan > Rp30 Milyar dengan menerbitkan Compliance Financing Review terhadap 63 (enam puluh tiga) usulan pembiayaan maupun perpanjangan dan restrukturisasi.

Pelaksanaan secara sederhana yang lainnya juga ditemukan pada BCA Syariah dan Victoria Syariah. Pelaksanaan fungsi kepatuhan pada BCA Syariah masih terbilang umum, belum ditemukan unitunit khusus yang menangani pemantauan terhadap prinsip kehati-hatian. Pelaksanaan fungsi kepatuhan fokus pada dua hal utama, yaitu peningkatan peran dan fungsi kepatuhan melalui peran aktif direksi dan pengawasan aktif dewan komisaris dan satuan kerja kepatuhan, serta yang kedua yaitu pengelolaan risiko kepatuhan. Sedangkan pada Bank Victoria Syariah pelaksanaan fungsi kepatuhan juga masih terlaksana sebagaimana bank umum syariah pada umumnya, belum ditemukan satuan kinerja yang secara khusus menangani pemantauan prinsip kehati-hatian.

Dari beberapa model pemantauan dan pelaksanaan fungsi kepatuhan, setiap perbankan memiliki cara dan unit yang berbeda-beda dalam melaporkan. Diantara beberapa perbankan, ada sebagian yang memaparkan fungsi kepatuhan secara komprehensif, bahkan dalam pelaporan ada yang mengupayakan untuk menyampaikan informasi tersebut melalui beberapa unit khusus yang menangani proses pemantauan prinsip kehati-hatian. Hal tersebut sejauh ini telah dilakukan oleh beberapa Bank Umum Syariah di Indonesia, diantaranya yaitu BNI Syariah, Panin Bank Syariah, MayBank Syariah Indonesia, Bank Mega Syariah, Bank Muamalat Indonesia, serta BSM syariah. Namun di luar yang disebutkan diatas, sebagian besar hanya melaporkan kinerja atas fungsi kepatauhan maupun proses pemantauan prinsip kehati-hatian secara sederhana, atau dalam kata lain unit-unit yang menangani realisasi fungsi kepatuhan masih terlaksana secara sederhana.

\section{KESIMPULAN DAN IMPLIKASI}

Meningkatnya perkembangan industri perbankan syariah di Indonesia harus diiringi dengan meningkatnya tata kelola lembaga termasuk pemenuhan terhadap prinsip-prinsip syariah. Pemenuhan terhadap prinsip-prinsip syariah merupakan modal penting bagi perbankan syariah dalam meningkatkan kredibilitas dan eksistensinya di tengah masyarakat. Salah satu bentuk pemenuhan terhadap fungsi kepatuhan terwujud dalam bentuk pemantauan terhadap prinsip kehati-hatian, pemantauan terhadap prinsip kehatihatian ini meliputi berbagi hal yang berhubungan dengan operasional, produk, SDM, serta transaksi lain pada bank syariah. Dari penemuan atas penyelidikan pada laporan tata kelola perbankan syariah ditemukan beberapa hasil, diantaranya yaitu penerapan pemantauan prinsip kehati-hatian pada masing-masing perbankan berbeda terhadap yang lainnya. Sejauh ini, dari 10 laporan tata 
kelola perbankan yang diselidiki, hanya beberapa perbankan

yang mengimplementasikan pemantauan terhadap prinsip kehati-hatian. Diantara perbankan yang menerapkan pemantauan tersebut yaitu BNI Syariah, Panin Bank Syariah, MayBank Syariah Indonesia, Bank Mega Syariah, Bank Muamalat Indonesia, serta BSM syariah. Selain ke enam bank tersebut, hampir sebagian besar melaporkan aktiftias pemenuhan kepatuhan syariah secara simpel dan kurang memisahkan masing-masing unit kerja.

\section{DAFTAR PUSTAKA}

Anshori, A. G. (2010). Pembentukan bank syariah melalui akuisisi dan konversi: (pendekatan hukum positif dan hukum islam). Yogyakarta: UII Press.

Ardhaningsih, G. S. (2012). Sharia compliance akad murabahah pada BRI Syariah KCI Surabaya Gubeng. Universitas Airlangga, Surabaya.

Arifin, Z. (2009). Dasar-dasar manajemen bank syariah. Tangerang: Aztera Publisher.

Bank Indonesia. (2011). Peraturan Bank Indonesia Nomor 13/2/pbi/2011 tentang Pelaksanaan Fungsi Kepatuhan Bank Umum.

Burhanuddin, S. (2010). Aspek hukum lembaga keuangan syariah (Pertama). Yogyakarta: Graha Ilmu.

Faozan, A. (2013). Implementasi good corporate governance dan peran dewan pengawas syariah di bank syariah. La_Riba, 7(1), 1-14. https://doi.org/10.20885/lariba.vol 7.iss1.art1

Ilhami, H. (2009). Pertanggungjawaban dewan pengurus syariah sebagai otoritas pengawas kepatuhan syariah bagi bank syariah. Jurnal Mimbar Hukum, 21(3), 17.
Khoirudin, A. (2013). Corporate governance dan pengungkapan islamic social reporting pada perbankan syariah di indonesia. 6.

Machmud, A., \& Rukmana. (2010). Bank Syariah: Teori, kebijakan, dan studi empiris di Indonesia. Jakarta: Erlangga.

Mardiyah, Q., \& Mardian, S. (2015). Praktik audit syariah di lembaga keuangan syariah Indonesia. Akuntabilitas, 8(1), 01-17.

Nurhikmah, F., \& Kusumaningtyas, M. (2018). Pengaruh dewan pengawas syariah dan intellectual capital terhadap pengungkapan corporate social responsibility dengan kinerja keuangan sebagai variabel mediasi (studi empiris perbankan syariah di indonesia). Journal of Islamic Banking and Finance, 2(2), 15.

OJK. (2019). Perbankan Syariah. Diambil dari https://ojk.go.id/id/kanal/syariah/t entang-syariah/Pages/PerbankanSyariah.aspx

Prabowo, B. A., \& Jamal, J. B. (2017). Peranan Dewan Pengawas Syariah terhadap Praktik Kepatuhan Syariah dalam Perbankan Syariah di Indonesia. Jurnal Hukum Ius Quia Iustum Faculty of Law, 24(1).

Prasetyoningrum, A. K. (2010). Analisis Pengaruh Independensi dan Profesionalisme Dewan Pengawas Syariah terhadap Kinerja Bank Perkreditan Rakyat Syariah di Jawa Tengah. Aset, 12(1), 27-36.

Riani, \& Mardian, S. (2017). Dinamika kualitas audit di perbankan syariah di Indonesia. Jurnal Akuntansi dan Keuangan Islam, 5(2), 177-194.

Shomad, A. (2010). Hukum islam: Penormaan prinsip syariah dalam hukum indonesia. Jakarta: Kencana. 
Sutedi, A. (2009). Perbankan syariah: Tinjauan dan beberapa segi hukum. Jakarta: Ghalia Indonesia.

Usman, R. (2001). Aspek-aspek hukum perbankan Indonesia. Jakarta: Gramedia.

Widyanto, E. A. (2010). Peran independensi dewan pengawas syariah terhadap loyalitas penerapan syariat islam. Jurnal Eksis, $6(2), 5$.

Yazid, H., \& Suryanto, T. (2016). An Investigation of Factors Influencing Audit Quality According to Islamic Audit: A Study for the Jakarta Islamic Index. International Journal in Economics and Business Administration, 4(1), 20-38. 